\title{
A review of health system infection control measures in developing countries: what can be learned to reduce maternal mortality
}

\author{
Julia Hussein ${ }^{*}$, Dileep V Mavalankar ${ }^{2}$, Sheetal Sharma ${ }^{3}$ and Lucia D'Ambruoso
}

\begin{abstract}
A functional health system is a necessary part of efforts to achieve maternal mortality reduction in developing countries. Puerperal sepsis is an infection contracted during childbirth and one of the commonest causes of maternal mortality in developing countries, despite the discovery of antibiotics over eighty years ago. Infections can be contracted during childbirth either in the community or in health facilities. Some developing countries have recently experienced increased use of health facilities for labour and delivery care and there is a possibility that this trend could lead to rising rates of puerperal sepsis. Drug and technological developments need to be combined with effective health system interventions to reduce infections, including puerperal sepsis. This article reviews health system infection control measures pertinent to labour and delivery units in developing country health facilities. Organisational improvements, training, surveillance and continuous quality improvement initiatives, used alone or in combination have been shown to decrease infection rates in some clinical settings. There is limited evidence available on effective infection control measures during labour and delivery and from low resource settings. A health systems approach is necessary to reduce maternal mortality and the occurrence of infections resulting from childbirth. Organisational and behavioural change underpins the success of infection control interventions. A global, targeted initiative could raise awareness of the need for improved infection control measures during childbirth.
\end{abstract}

Keywords: maternal mortality puerperal sepsis, infection control, nosocomial infections, health systems, developing countries

\section{Introduction}

The importance of a strong health system as the essential route to achieving improvements in maternal health and reductions in maternal mortality is widely accepted [1]. Effective coverage of maternity services requires timely and affordable access, by all sectors of the population, to appropriate care of sufficient quality and safety to help assure positive health outcomes. Good access, safety and quality are the overriding aims of all health systems and such factors are crucial when considering the problem of infections resulting from childbirth. Improving and maintaining infection control as part of delivery care requires an efficiently functioning health system.

Labour and delivery are especially hazardous times of pregnancy. Apart from the risks of severe bleeding and

\footnotetext{
* Correspondence: j.hussein@abdn.ac.uk

'University of Aberdeen, Foresterhill, Aberdeen, UK

Full list of author information is available at the end of the article
}

obstructed labour, life threatening infections can be introduced into the mother and baby's organs and bloodstream. 'Maternal sepsis' is a general term which has been used to include various obstetric and genito-urinary tract infections introduced into the mother [2]. The World Health Organization ranks maternal sepsis as the sixth leading cause of disease burden for women aged 15-44 years, after depression, HIV/AIDs, tuberculosis, abortion and schizophrenia. As many as 5.2 million new cases of maternal sepsis are thought to occur annually and an estimated 62,000 maternal deaths will result from the condition [2]. Added to the burden of loss of women's lives caused by sepsis are the long term consequences of infertility and the association of maternal sepsis with over one million infection related neonatal deaths every year $[3,4]$.

A specific form of maternal sepsis is known as puerperal sepsis, an infection which is introduced during childbirth, but manifests in the post partum period within the
C Biomed Central

다 2011 Hussein et al; licensee BioMed Central Ltd. This is an Open Access article distributed under the terms of the Creative Commons Attribution License (http://creativecommons.org/licenses/by/2.0), which permits unrestricted use, distribution, and reproduction in any medium, provided the original work is properly cited. 
first 42 days after delivery. It is of special importance because it is a serious, life threatening disease of the mother with infection of the womb and abdominal cavity, bloodstream infection, fever and pain [5]. In industrialized countries, puerperal sepsis is rare, causing $2.1 \%$ of maternal deaths. In Latin America and the Caribbean, its contribution to maternal mortality is $7.7 \%$, ranking lower than hypertensive disorders, haemorrhage, obstructed labour and abortion. In Africa and Asia, it is the second commonest cause of maternal mortality after haemorrhage, causing $9.7 \%$ and $11.6 \%$ of deaths respectively [6]. Other infections resulting from childbirth cause a considerable burden of morbidity and include infections of the genital tract, Caesarean section wound infections and urinary tract infections, but are usually not life threatening.

In developing countries, many women still deliver at home, making prevention of infection at home and in the community important, especially if family members and traditional birth attendants are unaware of the need for infection prevention. The provision of delivery care by health professionals and in health facilities is expected, and indeed, likely to decrease infection rates because of use of clean practices, sterile gloves and instruments. Yet the tumultuous history of puerperal sepsis and its association with institutional delivery care and the birth attendant is well recorded. Infective organisms causing puerperal sepsis are often introduced when the birth attendant conducts invasive procedures such as vaginal examination, instrumental or caesarean delivery. When childbirth in hospitals became more common in Western countries in the early $20^{\text {th }}$ century, an increase in maternal mortality occurred, much of which was due to spread of infection between women in labour by the attending health professional and use of invasive obstetric procedures [7]. This occurred despite knowledge of how infections were spread which dated back to the mid $19^{\text {th }}$ century. Increasing concerns of hospital and healthcare associated infections are also currently recorded across many medical disciplines, even in high income, industrialised countries [8]. Given these experiences, the increasing use of health facilities for childbirth in developing countries [9] calls for an attitude of watchfulness. In India, for example, the national policy promotes institutional deliveries which have steadily increased in the last 15 years from $26 \%$ to $41 \%[10,11]$. Studies here have shown that sepsis could be responsible for as much as $40 \%$ of maternal deaths $[12,13]$. In Mexico, $84 \%$ of deliveries occur in health facilities and rising Caesarean section rates were over $27 \%$ in the public sector and $70 \%$ in the private sector in 2005 [14]. Here, septic shock has been documented to account for as much as 5 to $10 \%$ of mortality [15]. There is no direct evidence of infection rates rising as a result of increasing institutional delivery rates. However, it is plausible that increasing utilisation of under resourced health facilities can result in stresses to the health system, overcrowding, poor environmental conditions, overworked health workers, shortages of drugs and supplies and sub standard clinical practices. These falling standards of care may include deteriorating infection control practices, resulting in an increased risk of institutionally acquired puerperal sepsis.

The epidemiology and aetiology of puerperal sepsis and other infections resulting from childbirth in developing countries are reviewed elsewhere [6,16-18]. Specific interventions necessary to prevent and treat infections are well known and include good hand hygiene, antisepsis, surgical sepsis and antibiotics. However, evidence on the more complex interventions relating to improvement of compliance, practice and behaviour is less well documented. Drawing from the broader infection control literature, this article reviews health system infection control measures pertinent to labour and delivery units in developing country health facilities.

\section{Methods}

A structured literature review was conducted between March and May 2009. The objective of the review was to inform the development of strategies to prevent infections transmitted during labour and delivery in developing country health facilities. We searched for literature which described infection control measures. Evidence of effectiveness was of interest, but we did not restrict our review to these studies as we wished to ascertain whether ideas were being tried out that required further testing. We anticipated that infection control measures were likely to be implemented within wider health system activities, so we did not confine our search only to maternity care.

The review was structured in so far as a list of terms was defined and used to search electronic data bases in a methodological manner, but was not intended to be a systematic review with pre-defined data extraction forms, plans for data synthesis, quality assessment or specific selection criteria [19]. The electronic bibliographic databases MEDLINE, EMBASE, CINAHL, POPLINE and the Cochrane library were searched to 2009 with no earlier date or language restriction. The databases were searched using the following terms alone and in combination: infection control AND [mater* OR neonat* OR health care OR health system OR quality care] AND [sepsis OR infection] AND [control OR prevent*]. No language restrictions were applied. Over 2000 articles were initially found. The titles and abstract of the articles were screened. First, articles on infection control interventions in community settings, antenatal care, abortion care, interventions directed specifically at the child or neonate and on specific infections (e.g. malaria, tuberculosis, HIV) were excluded. In a 
second step, we attempted to find articles from developing countries and related to infection during childbirth and safe or clean delivery. Almost no relevant articles were identified, so we included articles of general infection control measures and from developed countries. This yielded 116 articles.

The abstracts of these 116 resulting articles were scrutinised by two of the authors independently and in some cases, full texts were retrieved with 54 articles eventually found to be relevant to our objective. The selection of these 54 articles was not based on specific criteria, but on subjective decision making based on whether the article provided useful information on potential means to prevent infection transmission in labour and delivery units and whether interventions described were likely to overcome problems and challenges relevant to health systems in low resource settings.

Websites were searched based on the authors pre-existing knowledge of international agencies working in relevant areas, including United Nations agencies (UNICEF, UNFPA, World Health Organization); maternal health groups (American College of Nurse Midwives, Engender Health, International Confederation of Midwives, International Federation of Gynaecologists and Obstetricians, JHPIEGO, John Snow Inc, Partnership for Maternal, Newborn and Child Health); and quality, patient safety and surveillance organisations (Agency for Healthcare Research and Quality, Centres for Communicable Diseases, National Institute for Health and Clinical Excellence, Patient Safety Alliance, Quality Assurance Project). Web based citations from published papers were also searched.

\section{Findings}

The articles included had a global or overall developing country perspective. Reviews and guidelines were found (Table 1) and primary studies seeking to evaluate the effects of various infection interventions (Table 2). The developing countries included in the studies were in Asia (Nepal, India, Pakistan, Thailand), Africa (Egypt, Malawi, Mozambique, South Africa) and South America (Argentina and Columbia).

Characteristic problems related to infection control in developing countries include bad antibiotic prescribing practices, poorly functioning laboratory services, lack of surveillance data and sub-optimal design or construction of buildings and water and sanitation systems. Overcrowding of facilities and insufficient numbers of health workers are commonly noted. Increased bed numbers, nurse to patient ratios and bed space are known to have negative effects on infection transmission. Managers roles are not well specified, which contributes to the poor quality of services [20-23]. The combination of limited resources and general health conditions such as malnutrition, anaemia, and underlying infectious disease pose added risks [24]. Given such challenges, establishment of good infection control practices are believed to require a broad spectrum of interventions which address the availability and use of appropriate technologies, clear procedural guidelines and functionality of the health system [25-27].

Technological advances for preventing and treating puerperal sepsis in health facilities have been reviewed elsewhere and include supplies and equipment such as hand rubs and low cost disposable equipment, improved antibiotics and other drugs for treatment of severe infections, and microbiological diagnostic techniques [25,27]. Alcohol based antiseptic products are more efficacious than soap and water in reducing bacterial counts, and are convenient to use especially in basic health facilities where supplies of running water may be limited $[21,28,29]$. Systematic reviews have not however, found an established link between use of hand hygiene products and reductions in nosocomial infections [30]. The application of antiseptic washes to the vaginal area during labour has received much current interest, but there is insufficient evidence of its effectiveness in preventing maternal infection $[27,31,32]$.

The World Health Organization's Global Patient Safety Challenge was set up to highlight the need for multimodal approaches to prevent health care associated infections alongside technological innovations [26,33]. Increasingly, multifaceted and multicomponent interventions, which draw from psychological, educational, organisational, administrative, technological and medical perspectives, are being evaluated [34]. Such interventions, which are implemented either alone or in combination, include guideline use, education and training, organisational change, surveillance and quality improvement.

\section{Guidelines}

Various guidelines or procedural documents describing actions or recommended practices for infection control, for industralized and low resource settings have been issued. Examples are provided in Table 1. Some guidelines, such as those on hand hygiene, are highly specific and have been developed using quality assessed evidence meticulously gathered from reviews of literature. These have been the product of work done as part of the Global Patient Safety Challenge which targeted hand hygiene as a flagship campaign $[24,35]$. The effect of issuing new infection control guidelines specifically for promoting hand hygiene was evaluated across 40 hospitals in the USA [36]. No change in hand hygiene practices were found despite apparent uptake of the guidelines into hospital policies (Table 1). The lack of a comprehensive approach involving various levels within the organization, poor administrative support and absent feedback 
Table 1 Examples of infection control guidelines

\begin{tabular}{|c|c|c|c|}
\hline Guideline & Focus & Description & References and weblinks \\
\hline $\begin{array}{l}\text { Infection Prevention } \\
\text { Guidelines for Healthcare } \\
\text { Facilities with Limited } \\
\text { Resources (JHPIEGO) }\end{array}$ & $\begin{array}{l}\text { General } \\
\text { infection } \\
\text { prevention }\end{array}$ & $\begin{array}{l}\text { Tailored to low resource situations and for adaptation to } \\
\text { the local setting. Targets education and behaviour } \\
\text { change in both outpatient and hospitals settings and } \\
\text { includes general medical, surgical, and obstetric services. } \\
\text { It is one of a series of manuals, resource packages and } \\
\text { videos on infection control. The manual covers } 4 \text { main } \\
\text { areas: General infection prevention; processing of } \\
\text { instruments; gloves and other items; implementing } \\
\text { infection prevention in healthcare facilities; nosocomial } \\
\text { infections. }\end{array}$ & $\begin{array}{l}\text { Tietjen, Bossemeyer \& Mclntosh } 2003 \text { [58] } \\
\text { http://www.reproline.jhu.edu/english/ } \\
\text { 4morerh/4ip/IP_manual/ipmanual.htm }\end{array}$ \\
\hline
\end{tabular}

Practical Guidelines for Infection Control in Health Care (World Health Organization)

\section{General} infection prevention Provides comprehensive information to health care workers on the prevention and control of transmissible workers on the prevention and control of transmissible
infections. Builds on international guidelines and applies these to the needs of developing countries in Asia. Provides directions and information in relation to: Facilities, equipment, and procedures; cleaning, disinfecting and reprocessing of reusable equipment; waste management; protection of health care workers from transmissible infections; infection control practices in special situations.

Guide to the Implementation Hand of the Multimodal Hand hygiene Hygiene Improvement Strategy (World Health Organization)

Guideline for Hand Hygiene in Health Care Settings (Centres for Disease Control)

\section{Targets health care facilities with all levels of resource} availability. Concentrates on increasing compliance by health care workers. Main components: Improvement of infrastructure for hand hygiene; increase in knowledge and perception about hand hygiene, health care associated infection and patient safety.

\section{Provides health care workers with evidence and} recommendations to promote improved hand hygiene practices and reduce infection transmission to patients and personnel. Describes physiological and pathological processes and defines key terms used in infection control. Reviews efficacy of various hand hygiene products and practices.
Guidelines for Environmental Environment Aims to provide evidence-based recommendations for Infection Control in Health Care Facilities (Agency for Healthcare Research and Quality, USA) environmental infection control in health-care facilities. The control measures are focused on prevention of infections associated with air, water, surfaces, laundry and bedding, medical wastes and animals of the environment. It is based on recommendations of the Centres for Disease Control and the Healthcare Infection Control Practices Advisory Committee in the USA.

One of a series of infection control guidelines issued by

Clinical Guideline for Surgical Surgical Site Infection, (National Collaborating Centre for Women's and Children's procedures Health and the National Institute for Health and Clinical Excellence, UK)
NICE. D the prevention and treatment of surgical site infection except for specified specialised areas. The document reviews the evidence and provides recommendations for all procedures during the preoperative, intraoperative and postoperative phases of surgery.
World Health Organization 2004 [59] http:// www.searo.who.int/LinkFiles/ Publications_PracticalguidelinSEAROpub-41. pdf

WHO 2009 [60] http://www.who.int/entity/ gpsc/5may/Guide_to_Implementation.pdf of

\section{Boyce \& Pittet 2002 [29] http://www.cdc.} gov/hicpac/pubs.html http://www.guideline.gov/summary/ summary.aspx?doc_id=3843\&ss=15[61] mechanisms were thought to have been reasons for the failure to change practice.

\section{Education}

Educational interventions were categorised as those which improve skills or knowledge by training activities or by providing feedback on performance. In Argentina, an educational strategy which combined training sessions and performance feedback was used to improve hand hygiene in an intensive care unit. Focused, frequent education sessions were provided to health care workers. The education sessions emphasised the use of guidelines on hand hygiene and also fed back information to health workers on performance [37]. Hand washing compliance was observed covertly and infection rates improved markedly over the 16 months after the intervention was initially introduced (Table 2). Similar effects from education and performance feedback were noted in other settings in Argentina [38].

\section{Organisational and systems changes}

Organisational and systems interventions were those that involved administrative, budgetary or management inputs, adjustments to staffing structures or roles and 
Table 2 Studies on effectiveness of multifaceted infection control measures

\begin{tabular}{|c|c|c|c|c|c|c|}
\hline Intervention & Focus & Setting & Design & $\begin{array}{l}\text { Duration of } \\
\text { intervention }\end{array}$ & Key findings & Reference \\
\hline Issue of guidelines & $\begin{array}{l}\text { Centres for } \\
\text { Disease } \\
\text { Control hand } \\
\text { hygiene } \\
\text { guidelines }\end{array}$ & $\begin{array}{l}40 \text { hospitals, } \\
\text { USA }\end{array}$ & $\begin{array}{l}\text { Before and } \\
\text { after, no } \\
\text { control }\end{array}$ & $\begin{array}{l}2 \text { years, with } \\
\text { follow up for } \\
1 \text { year after } \\
\text { release of } \\
\text { guidelines }\end{array}$ & $\begin{array}{l}\text { All hospitals changed policies, } \\
\text { procedures and products after } \\
\text { guideline introduced } 90 \% \text { staff } \\
\text { were aware of guidelines No } \\
\text { change in hand hygiene } \\
\text { compliance }\end{array}$ & $\begin{array}{l}\text { Larson } \\
\text { et al } 2007 \\
\text { [36] }\end{array}$ \\
\hline $\begin{array}{l}\text { Education: Monthly meetings for } \\
\text { feedback; posted infection rates in } \\
\text { wards; voluntary educational group } \\
\text { sessions; distribution of infection } \\
\text { control manual }\end{array}$ & Hand hygiene & $\begin{array}{l}\text { Intensive care } \\
\text { units in one } \\
\text { hospital, } \\
\text { Argentina }\end{array}$ & $\begin{array}{l}\text { Before and } \\
\text { after, no } \\
\text { control }\end{array}$ & $\begin{array}{l}21 \text { months, } \\
\text { with } 16 \\
\text { month follow } \\
\text { up after } \\
\text { intervention }\end{array}$ & $\begin{array}{l}\text { Hand washing compliance } \\
\text { increased from } 23 \% \text { to } 65 \% \\
\text { Infection rates decreased from } 5 \text { to } \\
3 \text { per } 100 \text { patient days }\end{array}$ & $\begin{array}{l}\text { Rosenthal } \\
\text { et al } 2005 \\
\text { [37] }\end{array}$ \\
\hline $\begin{array}{l}\text { Organisational and systems } \\
\text { improvements: Interactive } \\
\text { development and placement of } \\
\text { posters; distribution of alcohol } \\
\text { based hand rub products; support } \\
\text { from senior management }\end{array}$ & $\begin{array}{l}\text { Hand hygiene, } \\
\text { particularly } \\
\text { alcohol based } \\
\text { hand rubs }\end{array}$ & $\begin{array}{l}\text { One hospital, } \\
\text { Switzerland }\end{array}$ & $\begin{array}{l}\text { Before and } \\
\text { after, no } \\
\text { control }\end{array}$ & $\begin{array}{l}3 \text { year follow } \\
\text { up after } \\
\text { intervention }\end{array}$ & $\begin{array}{l}\text { Consumption of alcohol hand rub } \\
\text { by volume increased from } 4 \text { to } 15 \\
\text { litres per } 1000 \text { patient days Hand } \\
\text { hygiene compliance increased from } \\
48 \% \text { to } 66 \% \text { Infection rates } \\
\text { decreased from } 17 \% \text { to } 10 \%\end{array}$ & $\begin{array}{l}\text { Pittet et al } \\
2000 \text { [28] }\end{array}$ \\
\hline $\begin{array}{l}\text { Surveillance, including: } \\
\text { Epidemiological analysis; } \\
\text { prioritisation of infection during } \\
\text { ward rounds; feedback to staff; } \\
\text { specialised infection control staff; } \\
\text { improved staff to bed ratios }\end{array}$ & $\begin{array}{l}\text { Urinary tract, } \\
\text { surgical, } \\
\text { bacteremic } \\
\text { infections and } \\
\text { pneumonia }\end{array}$ & $\begin{array}{l}\text { Representative } \\
\text { sample of } \\
4,000 \text { hospitals, } \\
\text { USA }\end{array}$ & $\begin{array}{l}\text { Quasi- } \\
\text { experiment- } \\
\text { al, with } \\
\text { regression } \\
\text { modelling }\end{array}$ & 5 years & $\begin{array}{l}\text { A maximum decrease in infection } \\
\text { rates by } 32 \% \text { if all components } \\
\text { implemented Most hospitals could } \\
\text { only achieve reductions in infection } \\
\text { rates of } 6 \% \text { Different combinations } \\
\text { of components were optimally } \\
\text { effective for different infections }\end{array}$ & $\begin{array}{l}\text { Haley } \\
\text { et al } 1980 \\
\text { [42] Haley } \\
\text { et al } 1985 \\
{[40]}\end{array}$ \\
\hline $\begin{array}{l}\text { Continuous quality improvement: } \\
\text { Teamwork; analysis of cause-effect } \\
\text { using problem based models; } \\
\text { prioritisation of specific actions } \\
\text { emerging from problem solving }\end{array}$ & $\begin{array}{l}\text { Caesarean } \\
\text { section }\end{array}$ & $\begin{array}{l}2 \text { obstetric } \\
\text { referral } \\
\text { hospitals, } \\
\text { Colombia }\end{array}$ & $\begin{array}{l}\text { Segmented } \\
\text { time series }\end{array}$ & 2 years & $\begin{array}{l}\text { Administration of antibiotic } \\
\text { prophylaxis increased from } 71 \% \text { to } \\
95 \% \text { in hospital A and from 36\% to } \\
89 \% \text { in hospital B } \\
\text { Downward trend in surgical site } \\
\text { infection rate in both hospitals }\end{array}$ & $\begin{array}{l}\text { Weinberg } \\
\text { et al } 2001 \\
{[45]}\end{array}$ \\
\hline
\end{tabular}

changes in policy or governance. A multimodal hand hygiene strategy comprising educational inputs, feedback and organisational change was evaluated in Switzerland [28]. The organisational interventions included ensuring that strong institutional support was developed by gaining involvement of clinical directors, obtaining funding from senior management budgets and ensuring that senior clinicians participated actively at meetings. Emphasis was placed on making individual bottles of hand rubs available and improving bedside access to hand hygiene products. The study showed improvements in hand washing compliance and infection rates (Table 2). Effects were followed up for over three years after the intervention package was introduced. Other studies have demonstrated similar effects but none for such a sustained period of time [29]. In Egypt, an organisational structure was set up to develop national guidelines, train and establish monitoring and evaluation systems, but no results on effectiveness of the programme were available [39].

Other organisational changes include reviewing health facility staffing and the way in which personnel are organised. These appear to be important aspects for success, along with professional infection control and clinical epidemiological expertise [40]. More recent studies have been conducted to establish the optimal knowledge and skills of infection prevention specialists and of staff-to-bed ratios, but clear recommendations on effective organisation of staff have not yet emerged [41].

\section{Surveillance}

A national epidemic of nosocomial staphylococcal infection in American hospitals in the 1950s and 1960s prompted a number of efforts to assess the effects of surveillance, which involves systematic monitoring of events or performance. Several uncontrolled studies in the 1970s subsequently demonstrated its effectiveness in reducing infection rates, but it was the seminal SENIC (Study on the Efficacy of Nosocomial Infection Control) findings which are of greatest interest $[40,42]$. The study identified the extent to which hospitals were conducting surveillance and showed that surveillance, combined with other infection control activities, led to reductions in nosocomial urinary tract infection, surgical wound infection and bacteraemia. Prevention of up to a third of infections could be achieved if maximum intensity activities were undertaken, but few hospitals managed to implement all components (Table 2). The components included surveillance, feedback, training and adequate staffing to bed ratios. An infection control nurse working 
with specially trained physicians or microbiologists with special interests in infection control was required to supervise the programme. Routine identification of nosocomial infections during clinical ward rounds, analysis of rates of infection using epidemiologic techniques, and periodic use of data generated in decision-making were also important. The exact combination of components that seemed to be the most effective varied for the different sites of infection. Of particular interest to maternity care, prevention of bacteraemia, which is the main condition associated with life threatening puerperal sepsis, required what was termed the highest 'intensity' activities - involving most or all of the components [40].

\section{Continuous quality improvement}

More recent studies have echoed the importance of multimodal, high intensity combinations. Real time reminders, provider audits, feedback and continuous quality improvement activities have been recommended [43]. Continuous quality improvement is a means of audit which follows a set process to create teamwork, identify problems and solutions and create shared goals using data for decision making [44]. A continuous quality improvement intervention was implemented in Colombia to improve infection rates after Caesarean section [45]. Surveillance systems and an infection control committee were set up. Multidisciplinary teams were formed. Individuals reviewed and summarised literature and discussed findings with team members as part of the educational process. The teams identified causes of infection relevant to their own context and developed realistic solutions according to the identified needs. The study found that prescribing practices for prophylactic antibiotic cover improved and infection rates dropped (Table 2). The cost investment for the intervention was reportedly modest, with activities conducted as part of routine clinical duties but specific data on time and monetary costs were not provided.

\section{Other infection control measures}

Mandatory public reporting mechanisms for health care associated infections and the use of benchmarking to identify better and less well performing institutions have also been proposed $[26,34,46]$. The effect of introducing opinion leaders to motivate and change the practice of clinicians has been assessed in a systematic review [47]. Opinion leaders were more effective than feedback of information and didactic educational meetings, but these findings were relevant to improving the quality of maternity care in general, and were not specific to infection control.

\section{Cost-effectiveness}

Cost-effectiveness data provide comparisons between the various costs and outcomes of two or more different interventions. The cost of extended hospitalisation due to infection is thought to exceed those of improving infection control measures. In the USA, reduction of infections by only $6 \%$ would offset the cost of an infection control programme by savings from reduced hospitalisation [40]. A systematic review of studies between 1990 and 2000, mostly from the USA, Canada and Europe, found that the costs attributable to bloodstream infections was the highest of different types of infection but lack of standardisation and methodological rigour of the studies constrained any conclusions [48]. A study in India showed that care for longer stay, hospital acquired bacteraemia in a cardiac hospital cost US $\$ 15,000$ more per patient, when compared to patients who did not develop infection [49]. In Mozambique, single dose prophylactic antibiotics at emergency Caesarean section was found to cost less than a tenth of a post operative, seven day regimen, with no significant difference in infection rates [50].

\section{Discussion}

The infection control measures described have been somewhat artificially categorised as it can be observed that each intervention, for example 'education' or 'surveillance' in fact comprises several other components such as performance feedback, use of guidelines or technological improvements. The least complex intervention found introduction of new clinical guidelines - was not found to result in practice change [36]. To achieve optimal reductions in infection rates, there is some evidence that multimodal and multifaceted interventions are effective [40,43]. Most current studies suffer from the limitations of quasiexperimental designs, the lack of controls and the multicomponent nature of the interventions. Evidence on costeffectiveness in infection control is lacking. There are few evaluations on infection control measures in labour and delivery, yet the principles of infection control remain the same across clinical areas and in different resource settings, so the findings of the studies are relevant to maternity care. The link between infection control, the quality and safety of services and health system factors is widely recognised $[21,29]$.

The findings of this review suggest a need to implement and evaluate complex and multifaceted approaches in obstetric units. The choice of the specific combination of components to be evaluated can be informed by what is known from the wider infection control literature, from existing information on ways to improve quality in maternity care and by tailoring strategies to address underlying problems of infection control [47]. Unnecessary or wasteful components need to be weeded out $[21,50,51]$. Measurement challenges remain and ways to standardise metrics across different settings, case mixes or facilities will allow better comparisons to be made 
between studies. Improvements of proxy indicators of morbidity, such as attributable length of stay have been called for [34] and may be especially relevant because puerperal sepsis is a comparatively rare event. For policy level decision making, the viability of allocating resources to infection control programmes would depend on demonstrating the merits between the costs of prevention and the costs of treatment [40]. The need for action in the implementation of infection control measures should not be seen as a competing priority with research support, especially where resources are limited. Studies of effectiveness should be designed to act as agents of change by also catalysing improvements in practice.

The interventions described in this review highlight the importance of behavioural change in the health workforce, yet such change is notoriously difficult to implement. Inadequate understanding of complex motivational factors may play a role [18]. Even if individuals are well motivated, working in a chaotic environment or a setting with poor infrastructure can be a barrier to change. Our knowledge of how specific characteristics or contexts affect behaviour is inadequate - for example, it is unclear why physicians and nursing assistants have been found to be poorer hand washers than nurses, or why compliance with infection control is more common during weekdays and in intensive care units [29]. Such uncertainties emphasise the need to study infection control interventions using a broad lens, combining knowledge from diverse perspectives such as psychology, education, organisational and management science and technology. Behavioural theories from models developed in psychology have been used to examine infection control practices such as hand washing in health care providers, concluding that it is the interdependence of various factors including environment, organisation and structure that matters, rather than individual behaviour [29]. Such understanding can help shape the design of appropriate interventions, so that instead of simplistic interventions targeting health workers to wash their hands, viable strategies are those that make changes which affect interactions between individuals, and how they function within their environment and their institutions. Recent expansion of patient safety initiatives in the developed world can be seen to draw from organisational, sociological and psychological theory $[52,53]$, and will provide future lessons for infection prevention in developing countries and for maternity care.

As one of the leading causes of maternal mortality in low and middle income countries, it is surprising how little attention has been paid to puerperal sepsis and infection control during childbirth. Globalization of health policy and consequent responses can have varying impacts. On the one hand, some targeted approaches which focus on single causes of maternal mortality and morbidity in developing countries appear to have created momentum and interest for specific conditions. For instance, considerable attention has recently been given to studying the use of misoprostol and other technologies to improve the management of post partum haemorrhage in several low and middle income nations [27]. Scaled up, multicentre research has provided unequivocal evidence of the efficacy of magnesium sulphate in preventing deaths from eclampsia [54]. Advocacy for the condition is now part of the Clinton Global Initiative Commitment and an International Call to Action has been developed [55]. A global campaign to end obstetric fistula is supported by an array of international organisations in which obstetric care to prevent obstructed labour is a core activity [56]. On the other hand, a high profile, World Health Organization supported Global Patient Safety Challenge focusing on infection control, $[26,33]$ has not resulted in actions to reduce infection risks in labour wards in developing countries.

An estimated 358,000 women die every year from the complications of childbirth and up to $15 \%$ of these are due to puerperal sepsis [57]. A simplistic extrapolation of the finding that infection rates can be reduced by $32 \%$ using optimal infection control measures [40], would suggest that the deaths of over 17,000 women could be prevented every year. Millions of women suffering from maternal sepsis and its long term consequences would also benefit. There should be no excuses for delaying targeted, global action to implement and evaluate infection control measures during labour and delivery for the prevention and reduction of puerperal sepsis and other related conditions.

\section{Conclusion}

This review has highlighted three overarching lessons related to infection control and maternal mortality reduction. Firstly, despite limited evidence on effective infection control measures during labour and delivery and from low resource settings, it appears that education, surveillance, organisational change and quality improvement interventions should be introduced, confirming the need for a health systems approach to reduce maternal mortality, especially in relation to sepsis. Second is the need to improve our understanding of organisational and behavioural change to effectively implement infection control measures. In doing so, we will need to be informed by diverse and multidisciplinary perspectives. Finally, globalized, targeted health policies or initiatives have the potential to bring attention to, and catalyse action for what is currently a neglected, but important cause of maternal death worldwide.

\section{Acknowledgements}

Leighton Walker assisted in finding some papers referenced in this review. Ethics Approval 
None required.

Funding

This literature review was conducted as part of a study on infection control during labour and delivery, funded by the John D. and Catherine T MacArthur Foundation http://www.macfound.org grant number 09-92855000-GSS. The funders had no role in study design, data collection and analysis, decision to publish, or preparation of the manuscript.

\section{Author details}

'University of Aberdeen, Foresterhill, Aberdeen, UK. ${ }^{2}$ Indian Institute of Management, Vastrapur, Ahmedabad, India. ${ }^{3}$ Bournemouth University, Bournemouth, UK.

\section{Authors' contributions}

All authors were involved in reading drafts of the manuscript and providing comments and suggestions for the paper. They have all approved the final version of the paper. $\mathrm{JH}$ and DM provided guidance on the framework and direction of the literature review. JH wrote and redrafted manuscripts and reviewed articles. SS conducted literature searches, reviewed articles, prepared drafts of tables and drafted the methods section. LD reviewed articles and provided substantive inputs on drafts of the manuscript.

\section{Competing interests}

The authors declare that they have no competing interests.

Received: 12 November 2010 Accepted: 19 May 2011

Published: 19 May 2011

\section{References}

1. Task Force on Child Health and Maternal Health and UN Millennium Project: Who's Got the Power? Transforming Health Systems for Women and Children London; 2005

2. World Health Organization: The Global Burden of Disease 2004 Update Geneva; 2008.

3. AbouZahr C: Global burden of maternal death and disability. British Medical Bulletin 2003, 67:1-11.

4. Lawn JE, Cousens S, Zupan J, Lancet Neonatal Survival Steering Team: 4 million neonatal deaths: When? Where? Why? Lancet 2005, 365(9462):891-900.

5. International Statistical Classification of Diseases and Related Health Problems 10th Revision (ICD-10). [http://apps.who.int/classifications/apps/ icd/icd10online].

6. Khan KS, Wojdyla D, Say L, Gülmezoglu AM, Van Look PF: WHO analysis of causes of maternal death: a systematic review. Lancet 2006, 367(9516):1066-1074.

7. Loudon I: The Tragedy of Childbed Fever Oxford: University Press; 2000.

8. Voss A: Healthcare associated infections. BMJ 2009, 339:932.

9. Stanton C, Blanc AK, Croft T, Choi Y: Skilled care at birth in the developing world: progress to date and strategies for expanding coverage. Journal of Biosocial Science 2007, 39(1):109-120.

10. National Rural Health Mission: About NHRM. [http://164.100.52.110/nrhm htm].

11. National Family Health Survey (NFHS-3), 2005-06: India: Volume I. Mumbai: IIPS. [http://www.measuredhs.com/pubs/pub_details.cfm? $\mathrm{ID}=723 \&$ ctry_id $=57 \&$ SrchTp=ctry\&flag=sur\&cn=India].

12. Anandalakshmy PN, Buckshee K: Maternal mortality in a referral hospital in northern India: a sixteen year review. Journal of Family Welfare 1997, 43:1-4.

13. Rajaram P, Agrawal A, Swain S: Determinants of maternal mortality: a hospital-based study from South India. Indian Journal of Maternal and Child Health 1995, 6:7-10.

14. Belizán JM, Althabe F, Barros FC, Alexander S: Rates and implications of caesarean sections in Latin America: ecological study. BMJ 1999, 319(7222):1397.

15. Villar J, Valladares E, Wojdyla D, Zavaleta N, Carroli G, Velazco A, Shah A, Campodónico L, Bataglia V, Faundes A, Langer A, Narváez A, Donner A, Romero M, Reynoso S, de Pádua KS, Giordano D, Kublickas M, Acosta A, WHO 2005 global survey on maternal and perinatal health research group: Caesarean delivery rates and pregnancy outcomes: the 2005 WHO global survey on maternal and perinatal health in Latin America. Lancet 2006, 367:1819-29.
16. Dolea C, Stein C: Global Burden of Disease. 2000 [http://www.who.int/ healthinfo/statistics/bod_maternalsepsis.pdf].

17. Seale AC, Mwaniki M, Newton CR, Berkley JA: Maternal and early onset neonatal bacterial sepsis: burden and strategies for prevention in subSaharan Africa. Lancet Infect Dis 2009, 9:428-38.

18. Hussein J, Walker L: Chapter 8 Puerperal sepsis in low and middle income settings: past, present and future. In Maternal and Infant deaths: Chasing Millennium Development Goals 4 \& 5. Edited by: Kehoe S,Neilson JP, Norman JE. London: RCOG Press; 2010:131-147.

19. Sander $L$, Kitcher $H$ : Systematic and other reviews: terms and definitions used by UK organisations and selected databases National Institute for Health and Clinical Excellence. [http://www.nice.org. uk/aboutnice/whoweare/aboutthehda/hdapublications/systematic_and_ other_reviews_terms_and_definitions_used_by_uk_organisations_and_ selected_databases_systematic_review_and_delphi_survey.jsp].

20. Raza MW, Kazi BM, Mustafa M, Gould FK: Developing countries have their own characteristic problems with infection control. Journal of Hospital Infection 2004, 57:294-299.

21. Hambraeus A: Lowbury Lecture: Infection control from a global perspective. Journal of Hospital Infection 2005, 64(3):217-223.

22. Shears P: Poverty and infection in the developing world: Healthcarerelated infections and infection control in the tropics. Journal of Hospital Infection 2007, 67(3):217-224.

23. Pittet D, Allegranzi B, Storr J, Nejad SB, Dziekan G, Leotsakos A, Donaldson L: Infection control as a major World Health Organization priority for developing countries. Journal of Hospital Infection 2008, 68:285-292.

24. Pittet D, Allegranzi B, Storr J, Donaldson L: 'Clean care is safer care': the global patient safety challenge 2005-2006. International Journal of Infectious Diseases 2006, 10(6):419-424

25. Hussein J, Fortney JA: Puerperal sepsis and maternal mortality: what role can new technologies play? International Journal of Gynecology \& Obstetrics 2004, 85(Suppl 1):S52-S61.

26. Pittet D: The crusade against puerperal fever. Lancet 2004 363(9417):1331-1332.

27. Tsu VD, Coffey PS: New and underutilised technologies to reduce maternal mortality and morbidity: what progress have we made since Bellagio 2003? BJOG 2009, 116(2):247-56.

28. Pittet D, Hugonnet S, Harbarth S, Mourouga P, Sauvan V, Touveneau S, Perneger TV, Members of the infection control programme: Effectiveness of a hospital-wide programme to improve compliance with hand hygiene. Lancet 2000, 356(9238):1307-1312.

29. Boyce JM, Pittet D: Guideline for hand hygiene in health-care settings. American Journal of Infection Control 2002, 30(1):1-46.

30. Backman C, Zoutman DE, Marck PB: An integrative review of the current evidence on the relationship between hand hygiene interventions and the incidence of health care-associated infections. American Journal of Infection Control 2008, 36:333-348.

31. Lumbiganon $P$, Thinkhamrop J, Thinkhamrop B, Tolosa JE: Vaginal chlorhexidine during labour for preventing maternal and neonatal infections (excluding Group B Streptococcal and HIV). Cochrane Database of Systematic Reviews 2004, 4:CD004070.

32. Stade BC, Shah VS, Ohlsson A: Vaginal chlorhexidine during labour to prevent early-onset neonatal group B streptococcal infection. Cochrane Database of Systematic Reviews 2004, 3:CD003520.

33. Pittet $D$, Donaldson L: Clean care is safer care: a worldwide priority. Lancet 2005, 366(9493):1246-1247.

34. Pittet D: Infection control and quality health care in the new millennium American Journal of Infection Control 2005, 33(5):258-267.

35. Allegranzi B, Storr J, Dziekan G, Leotsakos A, Donaldson L, Pittet D: The first global patient safety challenge "clean care is safer care": from launch to current progress and achievements. Journal of Hospital Infection 2007, 65(Suppl 2):115-123.

36. Larson EL, Quiros D, Lin SX: Dissemination of the CDC's Hand Hygiene Guideline and impact on infection rates. American Journal of Infection Control 2007, 35(10):666-675.

37. Rosenthal VD, Guzman S, Safdar N: Reduction in nosocomial infection with improved hand hygiene in intensive care units of a tertiary care hospital in Argentina. American Journal of Infection Control 2005, 33(7):392-397. 
38. Rosenthal VD, Guzman S, Pezzotto MS, Crnich CJ: Effect of an infection control program using education and performance feedback on rates of intravascular device-associated bloodstream infections in intensive care units in Argentina. American Journal of Infection Control 2003, 31:405-409.

39. Talaat M, Kandeel A, Rasslan O, Hajjeh R, Hallaj Z, El-Sayed N, Mahoney FJ: Evolution of infection control in Egypt: Achievements and challenges. American Journal of Infection Control 2006, 34(4):193-200.

40. Haley RW, Culver DH, White JW, Morgan WM, Emori TG, Munn VP, Hooton TM: The efficacy of infection surveillance and control programs in preventing nosocomial infections in US hospitals. American Journal of Epidemiology 1985, 121(2):182-205.

41. Stone PW, Dick A, Pogorzelska M, Horan TC, Furuya EY, Larson E: Staffing and structure of infection prevention and control programs. American Journal of Infection Control 2009, 37(5):351-357.

42. Haley >RW, Quade D, Freeman HE, Bennett JV, the CDC SENIC planning committee: Study on the efficacy of nosocomial infection control (SENIC Project): summary of study design. American Journal of Epidemiology 1980, 111(5):472-85.

43. Yealy DM, Auble TE, Stone RA, Lave JR, Meehan TP, Graff LG, Fine JM, Obrosky MS, Mor MK, Whittle Fine MJ: Effect of increasing the intensity of implementing pneumonia guidelines:a randomized, controlled trial. Annals of Internal Medicine 2005, 143(11):881-894.

44. Plsek PE: Quality improvement methods in clinical medicine. Pediatrics 1999, 103(1 Suppl E):203-14.

45. Weinberg M, Fuentes JM, Ruiz Al, Lozano FW, Angel E, Gaitan H, Goethe B, Parra S, Hellerstein S, Ross-Degnan D, Goldmann DA, Huskins C: Reducing infections among women undergoing cesarean section in Colombia by means of continuous quality improvement methods. Archives of Internal Medicine 2001, 161:2357-2365.

46. Stone PW, Horan TC, Shih HC, Mooney-Kane C, Larson E: Comparisons of health care-associated infections identification using two mechanisms for public reporting. American Journal of Infection Control 2007, 35(3):145-149.

47. Althabe F, Buekens P, Bergel E, Belizán JM, Campbell MK, Moss N, Hartwell T, Wright LL, Guidelines Trial Group: A behavioral intervention to improve obstetrical care. New England Journal of Medicine 2008, 358(18):1929-1940.

48. Stone PW, Larson E, Kawar LN: A systematic audit of economic evidence linking nosocomial infections and infection control interventions. American Journal of Infection Control 2002, 30:145-152.

49. Kothari A, Sagar V, Ahluwalia V, Pillai BS, Madan M: Costs associated with hospital-acquired bacteraemia in an Indian hospital: a case-control study. Journal of Hospital Infection 2009, 71(2):143-148.

50. Kayihura V, Osman NB, Bugalho A, Bergström S: Choice of antibiotics for infection prophylaxis in emergency cesarean sections in low-income countries: A cost-benefit study in Mozambique. Acta Obstetricia et Gynecologica Scandinavica 2003, 82(7):636-641.

51. Kunaratanapruk S, Silpapojakul K: Unnecessary hospital infection control practices in Thailand: a survey. Journal of Hospital Infection 1998 40(1):55-59.

52. Øvretveit J: Understanding and improving patient safety: the psychological, social and cultural dimensions. J Health Organ Manag 2009, 23(6):581-96.

53. Wright ER, Perry BL: Medical Sociology and Health Services Research Past Accomplishments and Future Policy Challenges. J Interprof Care 2006, 20(5):517-25.

54. Magpie trial collaborative group: Do women with pre-eclampsia, and their babies, benefit from magnesium sulphate? The Magpie Trial: a randomised placebo controlled trial. Lancet 2002, 359(9321):1877-90.

55. Eclampsia and Pre-eclampsia. [http://www.engenderhealth.org/our-work/ maternal/eclampsia.php].

56. Global Campaign to End Fistula. [http://www.endfistula.org/index.htm].

57. World Health Organization: Trends in maternal mortality 1990 to 2008. Estimates developed by WHO, UNICEF, UNFPA and the World Bank Geneva; 2010.

58. Tietjen L, Bossemeyer D, McIntosh $\mathrm{N}$ : Infection prevention guidelines for healthcare facilities with limited resources Maryland: JHPIEGO; 2003.

59. World Health Organization: Practical guidelines for infection control in health care. No. 41 III WPRO Regional Publication New Delhi; 2004.
60. World Health Organisation: A Guide to the Implementation of the WHO Multimodal Hand Hygiene Improvement Strategy. [http://www.who.int/ patientsafety/information_centre/documents/en/index.html].

61. Agency for Healthcare Research and Quality: Guidelines for Environmental Infection Control in Healthcare Facilities. [http://www.guideline.gov/ summary/summary.aspx?doc_id=3843\&ss=15].

62. NICE: Infection control, prevention of healthcare-associated infection in primary and community care United Kingdom: NHS; 2003.

doi:10.1186/1744-8603-7-14

Cite this article as: Hussein et al:: A review of health system infection control measures in developing countries: what can be learned to reduce maternal mortality. Globalization and Health 2011 7:14.

\section{Submit your next manuscript to BioMed Central and take full advantage of:}

- Convenient online submission

- Thorough peer review

- No space constraints or color figure charges

- Immediate publication on acceptance

- Inclusion in PubMed, CAS, Scopus and Google Scholar

- Research which is freely available for redistribution

Submit your manuscript at www.biomedcentral.com/submit
Biomed Central 